of young families as a significant condition of preservation of peace and stability in the country.

$$
\begin{array}{r}
\text { "SotsIs; Sotsiological issledovaniya", } \\
\text { M., 2011, N 10, pp. 8-98. }
\end{array}
$$

\title{
EDUCATION, YOUTH AND ISLAM: GROWING POPULARITY OF PRIVATE RELIGIOUS LESSONS IN DUSHANBE, TAJIKISTAN
}

M. Stephan of the Institute of Asian and African Studies, Humboldt University in Berlin, explains the constantly growing popularity of private religious lessons in Dushanbe by the fact that they contribute to satisfying the growing interest of the urban Moslem population in the foundations of Islam, help parents to tackle educational tasks and allow young Muslims to take part in public life and express their religious affiliation. Besides, the growing number of study groups at mosques shows the strengthening positions of Islam in Tajikistan, and at the same time the weakening of the state educational system.

According to a Tajik tradition, "javoni" ("youth") is the time when a Muslim prepares himself for fulfilling duties in the family, at work, and in social life. At this stage of the life cycle a special role is given to education ("tarbia"). This notion covers a whole range of educational and pedagogic measures which the elder members of society carry on in order to show a young person the "right way" ("rohi rost"), teach him to live according to the existing cultural tradition and system of relations. The Tajiks have always given special meaning and significance to religious education. Public polls carried out among the inhabitants of Dushanbe show that representatives of all social groups without exception consider the standards of Islam to be the most 
important regulator of public life. The traditional postulates like "religion" ("din"), education ("tarbia"), morality, modesty and the proper rules of behavior as Islam teaches us are taken for incontestable truths.

In the post-Soviet period religious education began to return gradually to the life of urban dwellers also in the form of religious lessons ("sabak") attended by the growing number of young people. Studies are organized on the basis of standard programs for previous religious schools at mosques ("Maqtab"). As a rule, students of these schools familiarize themselves with canonic texts "Chahor qitob" and "Haftiyak", and works by classics of Persian literature Saadi, Bedil and Hafiz. Students are also taught correct performance of religious rites, above all, prayers. They are told about the meaning, significance and order of fasts and ablutions. The study of religious literature is necessarily accompanied with moral instructions. The latter should teach adolescents discipline and show them how family and society life should be organized on the basis of religious laws. Such notion as "hurmat" ("respect," "homage") is of special significance. "Hurmat" is related to all questions pertaining to public, religious and political life of Muslims in the region, and it strengthens the authority of the older generation and its domination over the younger generation, relations between the believers and the Divine forces, just as the relations between sexes.

1 "The Collection (in four parts) of prosaic and poetic works in the Persian language by different authors is one of the standard study aids on whose basis one of the local Islamic traditions of the Muslim population of Tajikistan was formed. The collection contains the basic premises of Moslem faith and serves to pass from generation to generation the rules by which the relations in the family and local community are formed."

2 "The book containing excerpts from the Koran." 
The growing interest of parents in their children attending religious lessons can be explained by various reasons. The main one is that people connect with them their hope for the revival of old traditions which were interrupted by the years spent in the U.S.S.R. under the rule of atheists. Most of those who send their kids to religious schools are poor settlers from rural districts. Having been forced to abandon their native places and settle in modern urban districts, they found themselves torn off from the habitual way of life in which children grew in the community medium, learned customs and habits necessary for adult life, and became used to the important principles of human relations.

Besides, religious education has specific gender aspects. Young girls attend special lessons at which they are told how important it is to adhere to high moral principles ("sharmu hae") and to be modest and chaste, for if a woman smears her reputation, it has an adverse effect on all her relatives. Girls are taught to dress properly in accordance with tradition and the rules of faith, and also to manage household. In the words of one "bibihalifa" (tutoress) from Dushanbe, lessons should teach girls things to be done in family life. Taking into account the fact that most Tajik women have very few career prospects, the ability to acquire knowledge and practice of how to do house chores properly is vitally important to them. This is why many parents in Dushanbe prefer religious education for their daughters rather than secular one.

To learn the basic principles of Islamic morality is no less important for a young Tajik lad. According to tradition, he will be the mainstay for his wife and children, and will also have to support his elderly parents. Previously, young men gradually learned their duties, observing the life of their own family and the families of people around them. However, a very difficult economic situation in post-Soviet Tajikistan made serious corrections to family life. Many families were 
forced to leave their native places. Parents proved unable to rear and educate their children properly because many of them had to leave the Motherland for other countries in search of work and income, while many mothers, apart from doing household duties, face the urgent need to find a job to feed their kids. So quite a few adolescents and young men live freely, are unattended and without any control of old folk. This is why many parents regard religious upbringing and education a good measure of control over the behavior of their sons and daughters. Attending private religious lessons is for young people a form of leisure activity, and creates a feeling of closeness to the life of the local community, which is especially important for the children of migrants from rural districts.

One mullah by name of Inoyat gives everyday lessons to sixteen adolescents from 12 to 16 years of age at the local mosque. Lessons take place in the afternoon, which enables the students to join adult men in the evening common prayer, and also to help keep the mosque in order (clean rooms, make tea, etc.). In this way religious studies are an alternative to the street, that is, a place which has a negative connotation for the older generation of Dushanbe Muslims as the seat of alcoholism, drug addiction, crime, prostitution, etc.

Religious lessons put to rights the everyday life of waifs and strays, teach them responsibility and give them an opportunity to take part in public and religious life of their district. These lessons are not simply an acceptable alternative to the "street." With their help young flotsam and jetsam, city migrants living in the periphery and having few social contacts, if any, and who, due to their abject poverty, do not take part in public life, receive a place for themselves in a definite social structure and a system of social support, which gives them a feeling of belonging, can replace absent relatives, and makes it possible to integrate in the local medium. At the same time, attendance of 
mosque classes enables them to raise their self-esteem and status. Occupying the marginal position in society, they attend "sabak" in the hope that it will enable them to gain respect in their community and increase the chances of social mobility.

Despite their narrow special purpose, religious lessons in present-day Tajikistan grant an opportunity of personal development for part of young people. Even living in Dushanbe many young people do not have access to elementary education, let alone good one. Quite often, elder children in poor large families are forced to drop school in order to help in household chores and look after younger children (this concerns mainly young girls). To attend religious lessons is for them the only form of intellectual activity. In the process of studying religious literature they learn quite a few useful things. For instance, the need to memorize sacred texts and then recite them contributes to developing memory and improving articulation, and reverent attitude to sacred books is then passed to books in general. Besides, for some adolescents attending "sabak" is the only opportunity to get distracted from nail-biting and spend hours with people of the same age.

In Tajik society with its patriarchal ways, young people have to live within the bounds determined for them by older generations. Such state of affairs considerably limits the opportunities for personal development. In this respect the study of the foundations of Islam (despite the fact that it takes place with the knowledge and approval of senior people) brings certain entertainment and variety to young people, broadens their outlook and gives food for thought and an impetus to independent conclusions and discussions with their counterparts. Those who succeeded in breaking with strict rules and take their own way feel even more independent and free. An example of such "freethinking" is the independent choice of spiritual tutor. Some young men leave the 
tutor ("mullo") who received classical religious education ("peshhondagi") in Soviet times and choose a tutor from among those who received "new education" ("novhondagi"). As a rule, these tutors are young themselves, they know foreign languages, use modern means of communications, follow new trends in Islamic literature, and even dress differently than the old Islamic clergy. In the eyes of the latter these young people are the embodiment of "pure," "transnational Islam," which undermines the local age-old traditions.

It is not only young men, but girls too, who choose the "novhondagi." It is indicative that the main reason for this is the "alternative Islamic dress" of young women-tutors. They wear a wide veil and a head-kerchief tied in a special way. On the one hand, such manner to dress and other fashionable details (modern fabrics, cosmetics, manicured and painted nails show that "Islamic modern" has come to the Tajik capital, too, in which fashion and aesthetics are combined with moral principles, beauty and piety). On the other hand, wearing such clothes can be seen as a form of protest, and the desire to become self-asserted and recognized by other people as such. A young woman become "noticeable" when wearing a veil and head-kerchief, and this runs counter to the local ideas of female morality ("sharmu hae"), in accordance with which woman should never draw attention to herself.

In conclusion the author writes that religious lessons which become ever more popular in Tajikistan enable Tajik young people to broaden their horizons determined for them by the older generation and old traditions without entering into confrontation with their parents. At the same time, in the conditions of abject poverty and the lack of real career prospects, Islam offers urban young people a "noble" way to raise their social status. It "serves as a pillar for young people in their 
search for identity and their struggle to become recognized by society and to get the status of the "adults."

N. Shuvalova. "Referativny zhurnal 'Vostokovedeniye i Afrikanistika'”, Moscow,2011, No 4, pp. 56-61.

\section{Vasilyev, \\ Senior scholar (IFE of RAS) \\ PECULIARITIES OF STRUGGLE AGAINST TERRORISM IN CENTRAL ASIA UNDER CONTEMPORARY CONDITIONS}

Extremism and separatism in the Central Asian region as well as concomitant terrorism represent the complicated and multi-aspect phenomena with political, economic, social, criminal and military components. This region is marked by operations of international terrorist organizations or their branches, radical Islamic fundamentalists and extremist groups, which causes anxiety of both the states and of the whole world community. It is important to take into account the fact that their emergence has the internal reasons, which are similar in various countries. At the same time, their activities are firmly connected with ideological trends out of the boundaries of the region, while the terrorist organizations of Central Asia maintain close contacts with the international criminal community, which keeps under control the trade of arms, narcotics and people.

One should take into account that separatism represents by itself a definite political movement, while extremism and terrorism are the means of achievement of political aims, which may be and are widely used both by separatists and representatives of other political trends. In other words, if separatism is the substance of definite political ideas, extremism and terrorism are the forms of their realization. 